\title{
PERMAINAN TRADISIONAL JAMURAN: ANALISIS PENGETAHUAN GURU PAUD YOGYAKARTA DITINJAU DARI TAKSONOMI BLOOM
}

\author{
Avanti Vera Risti Pramudyani ${ }^{1}$ \\ Fakultas Keguruan dan Ilmu Pendidikan, Universitas Ahmad Dahlan \\ Email: avanti.pramudyani@pgpaud.uad.ac.id \\ APA Citation: Pramudyani, A.V.R. (2020). Tingkat Pengetahuan Guru PAUD Tentang Permainan \\ Tradisional Jamuran Bagi Anak Usia Dini. Jurnal Pelita PAUD, 4(1), 168-177. \\ doi: https://doi.org/10.33222/pelitapaud.v4i1.972
}

\begin{abstract}
Abstrak: Permainan Jamuran adalah permainan tradisional yang popular di PAUD dan sebagian besar guru memahami sebagai permainan yang mengembangkan kemampuan sosial emosional khususnya kemampuan kerjasama. Namun, apabila dikaji permainan ini mampu menjadi media untuk menstimulasi keenam aspek perkembangan anak. Penelitian ini bertujuan mengetahui tingkat pengetahuan guru dalam memanfaatan permainan Jamuran dalam pembelajaran PAUD dikaji dari taksonomi Bloom. Penelitian ini adalah penelitian dengan pendekatan kualitatif deskriptif. Instrumen pengumpulan data diperoleh dari wawancara, observasi, dan dokumentasi dengan validasi data menggunakan triangulasi teknik. Analisis data dalam penelitian ini menggunakan Miles and Huberman. Hasil penelitian menunjukkan, tingkat pengetahuan guru terbagi menjadi tiga level rendah, sedang, dan tinggi. Untuk level rendah guru masih memerlukan pengetahuan lebih banyak tentang permainan Jamuran agar dapat lebih memanfaatkan sarana stimulasi. Sedangkan pada level sedang dan tinggi pengetahuan yang dimiliki cukup sebagai dasar bagi guru untuk mengembangkan permainan Jamuran. Namun diharapkan guru terus meningkatkan kemampuannya agar sesuai dengan perkembangan keilmuan dan kebutuhan anak didik.

Kata kunci: pengetahuan guru, paud, permainan tradisional, jamuran
\end{abstract}

Abstract: Jamuran is a traditional game that popular at ECE and the majority of the teacher have understood this game only for cooperative ability. However, these games can be a media to stimulate six aspects of children. This study aims to know the level of the teacher's knowledge about the advantages of Jamuran on ECE learning process overview from Taksonomi Bloom. This is qualitative research with qualitative and descriptive approach. Data collected from an interview, observation, and documentation. The technical analysis data use Miles and Huberman. The result shows that the level of teacher's knowledge divides into three levels such as low, moderate, and high. For the lowest level, the teacher has to increase the knowledge about Games of Jamuran. Moreover, for the moderate and high level the knowledge it is enough for the teacher to develop games of Jamuran. However, they should increase their ability to adaption the developing of knowledge and children's need.

Keywords:teacher's knowledge, early childhood education, traditional games, jamuran

http://jurnal.upmk.ac.id/index.php/pelitapaud 


\section{Vol. 4 No. 2 Juni 2020}

\section{PENDAHULUAN}

Pengetahuan merupakan tingkatan paling dasar dalam taksonomi Bloom yang mampu memprediksi kemampuan seseorang dalam memahami sesuatu. Sebagaimana pendapat dari (Darmawan, I P. Ayub \& Sujoko, 2013), tujuan dari taksonomi Bloom adalah membantu mengklasifikasikan pernyataanperyataan yang dapat digunakan untuk memprediksi kemampuan seseorang seperti peserta didik.

Taksonomi Bloom dalam dunia pendidikan digunakan terutama untuk menyiapkan caloncalon guru yang nantinya menjadi ujung tombak pembelajaran. Dalam penyiapan guru, mereka dilatih untuk mendesain pembelajaran dengan dibantu oleh taksonomi Bloom dalam menyusun atau mengembangkan kurikulum. Taksonomi Bloom memiliki 3 cakupan yaitu kognitif, afeksi, dan psikomotor. Untuk aspek kognitif lebih kepada cakupan kemampuan yang kaitannya dengan ingatan atau pengenalan fakta tertentu dan skill intelektual. Ranah afektif menekankan pada perasaan, sikap, nilai, emosi. Sedangkan ranah psikomotor, kaitannya dengan kegiatan motorik (Krathwohl, 2002).

Taksonomi Bloom mengalami perubahan atau direvisi pada tahun 2010 dikarenakan; 1) diharapkan guru sebagai pendidik tidak melakukan pengembangan dari handbook dan menjadikan hanya sebagai dokumen; 2) memerlukan penyesuaian dengan pengetahuan dan pemikiran yang berkembang (Anderson, Lorin W. \& Krathwohl, 2010). Perubahan yang paling mendaasar adalah adanya revisi urutan taksonomi sintesis menjadi urutan ke enam dan evaluasi menjadi urutan ke 5.

Revisi lain terutama sub kategori contohnya dalam ranah pengetahuan cukup memberikan perubahan yang signifikan. Awalnya pengetahuan dibagi menjadi 3 bagian yaitu pengetahuan hal khusus, pengetahuan cara dan sarana, dan pengetahuan umum menjadi mengingat dengan subsub kategori atau unsurnya mengenali dan mengingat kembali (Krathwohl, 2002).

Pengetahuan sebagai dasar dalam sebuah klasifikasi ranah berpikir memiliki peran yang cukup signifikan. Dengan pengetahuan yang baik maka klasifikasi selanjutnya dapat diperkiraan juga akan baik. Sebagaimana pendapat dari (Pancaningrum, 2016), tingkat pengetahuan dalam taksonomi Bloom sebagai tingkat paling rendah menjadi dasar untuk mengembangkan ranah kognitif. Apabila guru memiliki tingkat pengetahuan akan suatu pembelajaran PAUD yang baik maka akan tercipta kegiatan pembelajaran yang baik.

Pengetahuan menjadi dasar dan bagian yang paling penting untuk mengembangkan ranah kognitif lainnya diperkuat oleh hasil penelitian (Whittington, Susie M.; Stup, 1997), dalam menganalisis pembelajaran yang dilakukan para profesor di Pennsylvania State University pada sesi perkuliahan selama 50 menit menunjukkan bahwa tingkat Taksonomi Bloom yang digunakan dalam pengelolaan pembelajaran yaitu pengetahuan $47 \%$, pemahaman $33 \%$, aplikasi $8 \%$, analisis $10 \%$, analisis antara $0-6 \%$, dan evaluasi $1 \%$. Dalam penelitian tersebut membuktikan bahwa level pengetahuan menggunakan prosentase paling besar hampir 50\% dari ranah kognitif, sehingga dapat dikatakan pengetahuan adalah hal utama yang wajib dimiliki oleh guru sebagai dasar mengembangkan proses pembelajaran.

Menurut (Wulandari, 2018), apabila guru memiliki pemahaman sebagai bagian dari taksonomi Bloom yang baik tentang PAUD maka akan menghasilkan guru yang kreatif dalam pembelajaran demikian juga sebaliknya. Salah satu bentuk kreatifvitas yang dapat dilakukan oleh guru adalah memanfaatkan potensi lingkungan sekitar seperti kekayaan budaya.

Permainan tradisional sebagai salah satu kekayaan budaya dapat dimanfaatkan oleh guru dalam mengembangkan kegiatan pembelajaran berbasis kearifan lokal seperti permainan tradisional. Sebagaimana kita ketahui bahwa permainan tradisional juga memiliki pengaruh yang positif dalam menstimulasi ke enam aspek perkembangan anak usia dini (Khasanah, Ismatul; Prasetyo, Agung; \& Rakhmawati, 2011).

Berbagai jenis permainan tradisional yang dimiliki Bangsa Indonesia dapat dimanfaatkan dalam pembelajaran. Khususnya di Daerah Istimewa Yogyakarta, terdapat 37 jenis permainan yang dapat guru pilih dan gunakan dalam proses pembelajaran. Hal tersebut 
sesuai dengan pendapat (Dharmamulya, dkk, 2005), terdapat 37 permainan tardisional di DIY dan terbagi menajdi 3 klasifikasi yaitu permainan bernyanyi dan bermain, kelompok bermain dan berpikir, serta kelompok bermain dan berkompetensi. Permainan tradisional kategori bernyanyi dan bermain menjadi jenis permainan yang sesuai bagi anak usia dini.

Menurut (Pramudyani, A. V. R., Kurniawan, M. R., Rasyid, H., Sujarwo, S., Utami, N. I., \& Vesiano, 2018), permainan Jamuran adalah salah satu permainan tradisional dengan kategori bernyanyi dan bermain yang sesuai dengan karakteristik anak usia dini. Dengan permainan ini anak akan mengembangkan ke enam aspek dalam diri anak, selain itu anak dapat mengembangkan imajinasi melalui bentuk aneka jamur yang mereka tunjukkan. Berikut ini gambar 1. menggambarkan bentuk permainan Jamuran yang anak lakukan:

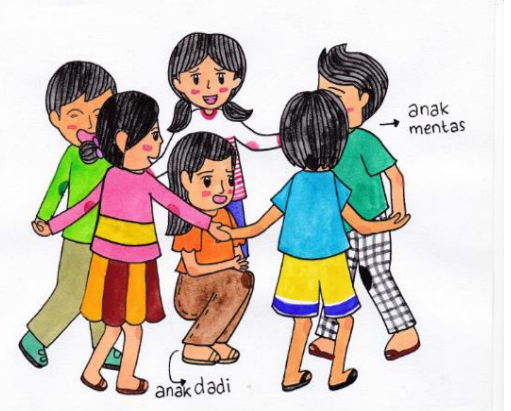

Sumber: (Pramudyani, A. V. R., Kurniawan, M. R., Rasyid, H., Sujarwo, S., Utami, N. I., \& Vesiano, 2018)

Gambar 1. Bentuk lingkaran permainan Jamuran

Jamuran adalah permainan tradisional yang sangat populer bagi anak usia dini. Dalam permainan tersebut anak dapat bergerak membentuk lingkaran, berbagai macam jamur, bergandengan, dengan aktivitas bernyanyi sehingga suasanya sangat riang gembira. Anak juga mengembangkan kemampuan kognitif dengan bermain simbol ketika membentuk berbagai mcam bentuk jamur sesuai dengan permintaan anak dadi. Manfaat lain dengan memainkan permainan ini adalah anak belajar mematuhi aturan, anak belajar mengekspresikan bahasa verbal atau non verbal, belajar kerjasama, dan bertanggung jawab (Pramudyani, A. V. R., Kurniawan, M. R., Rasyid, H., Sujarwo, S., Utami, N. I., \& Vesiano, 2018).
Memainkan Jamuran tidak memerlukan peralatan karena hanya dibutuhkan tempat terbuka yang cukup luas. Permainan ini dapat dimainkan oleh 4 sampai dengan 10 anak dengan 1 orang anak menjadi anak dadi, anak yang berada ditengah lingkaran yang bertugas untuk memberikan instruksi agar anak yang membuat lingkaran membentuk jamur tertentu. Anak dadi dapat berganti peran apabila ada anak yang membentuk simbol jamur yang tidak sesuai instruksi (Dharmamulya, dkk, 2005).

Meskipun permainan tradisional memiliki banyak manfaat dan mudah dimainkan masih banyak guru yang belum mengetahui hal tersebut. Berdasarkan hasil penelitian (Maryatun, I. B., Pamungkas, J., \& Christianti, 2017), masih banyak guru belum mampu mengembangkan pembelajaran berbasis budaya lokal seperti permainan tradisional. Ketidak mampuan guru dalam mengembangkan pembelajaran berbasis budaya lokal dikarenakan mereka belum memiliki pengetahuan akan hal tersebut.

Pengetahuan akan permainan tradisional sebagai aktivitas pembelajaran belum sepenuhnya diketahui guru diperkuat oleh hasil penelitian (Pramudyani, A. V. R., Kurniawan, M. R., Rasyid, H., 2017), kurang dari $50 \%$ guru di DIY masih menganggap permainan tradisional adalah kegiatan tambahan yang dilakukan diwaktu senggang. Guru cenderung memilih aktivitas permainan lain sebagai kegiatan utama dalam pembelajaran dibandingkan permainan tradisional. Pertimbangan guru tidak menggunakan permainan tradisonal karena ketidaktahuan mereka akan kebermanfaatannya sebagai aktivitas dengan mengembangkan ke enam aspek perkembangan anak.

Kurangnya pengetahuan guru juga disebabkan oleh kompetensi yang dimiliki guru. Sebagaimana kita ketahui kompetensi guru meliputi pedagogik, kepribadian, profesional, dan sosial. Kemampuan mengembangkan kegiatan pembelajaran dengan berbasis kearifan lokal seperti permainan tradisional adalah salah satu bentuk penguasaan kompetensi guru terutama dalam hal pengetahuan tentang pembelajaran anak usia dini sebagai bagian dari kompetensi pedagogik. Semakin baik kompetensi 
Vol. 4 No. 2 Juni 2020

pendidik maka akan semakin bagus kualifikasi yang dimilikinya yang berpengaruh pada kualitas pembelajaran seperti mampu menyediakan berbagai pengalaman belajar yang melibatkan lingkungan (Manning M, Garvis S, Fleming C, 2017). Hal tersebut menunjukkan bahwa apabila pengetahuan guru baik dan maka ia memiliki kompetensi yang baik pula dan berdampak pada penyiapan proses pembelajaran yang sesuai dengan kebutuhan dan mampu berkolaborasi dengan lingkunga.

Penelitian ini bertujuan untuk mengetahui tingkat pengetahuan guru khususnya di PAUD tentang permainan tradisional Jamuran. Tingkat pengetahuan dalam penelitian ini dikaji berdasarkan kalsifikasi Taksonomi Bloom.

\section{METODE PENELITIAN}

\section{Jenis Penelitian}

Penelitian ini menggunakan pendekatan kualitatif deskriptif (Miles, M. B., Huberman, M. A., \& Saldana, 2014). Penelitian ini dengan bertujuan memberikan gambaran tentang tingkat pengetahuan guru terkait permainan tradisional Jamuran dalam PAUD.

\section{Waktu dan Tempat Penelitian}

Penelitian dilakukan mulai dari April sampai dengan November 2018. Tempat penelitian dilaukan di PAUD khususnya layanan TK yang berada di wilayah Daerah Istimewa Yogyakarta yaitu Kota Yogyakarta, Kabupaten Sleman, Kabupaten Bantul, dan Kabupaten Gunung Kidul.

\section{Subjek Penelitian}

Subjek penelitian ini adalah 40 guru TK yang mengajar di layanan TK swasta ataupun negeri di 4 wilayah DIY.

\section{Prosedur}

Prosedur penelitian kualitatif deskripti dalam penelitian ini didasarkan pada (Sanjaya, 2015) dengan langkah berikut:

1. Mengidentifikasi masalah, peneliti melakukan identifikasi terkait masalah yang muncul yang berkaitan dengan tema penelitian dan merumuskan asumsiasumsi.

2. Merumusakan masalah dan mematasi masalah, masalah yang sudah teridentifikasi dan dipaparkan selanjutnya disusun rumusannya.

3. Melakukan studi pustaka, agar memperoleh pemahaman yang lebih luas dan dalam peneliti melakukan studi pustaka sehingga tersusun kerangka berpikir.

4. Mengembangkan insrumen penelitian agar sesuai dengan masalah yang diteliti.

5. Menentukan subjek penelitian yang berfungsi sebagai sumber data.

6. Melaksanakan penelitian sesuai dengan pedoman dan kisi-kisi penelitian.

7. Mengalisis data yang terkumpul dari instrumen yang digunakan.

8. Membahas hasil penelitian dan menarik kesimpulan. Hasil penelitian dilakukan proses intepretasi dan dibandingkan dengan teori yang diajukan dalam studi pustaka. Selanjutnya dilakukan penarikan kesimpulan berdasarkan data dan pembahasan.

9. Menyusun laporan dan mempublikasikan hasil penelitian kedalam jurnal agar dapat bermanfaat lebih luas.

\section{Data, Intrumen, dan Teknik Pengumpulan Data}

Data dikumpulkan melalui tiga instrumen yaitu wawancara secara tidak terstruktur ke guru sebagai subjek penelitian dengan menggali pengetahuan yang mereka miliki mengenai permainan tradisional Jamuran. Selain itu juga menggunakan instrumen observasi untuk memperoleh data gambaran proses pembelajaran yang memanfaatkan permainan tradisional Jamuran. Data juga du

\section{Teknik Analisis Data}

Teknik analisis data menggunakan (Miles, M. B., Huberman, M. A., \& Saldana, 2014), data yang dikumpulkan kemudian direduksi, disajikan, dan ditarik kesimpulan. Sebagaimana gambar 2. Bentuk teknik analisis dibawah ini:

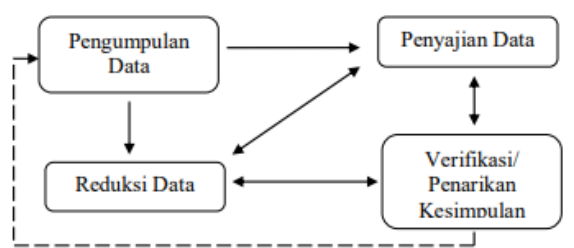


Vol. 4 No. 2 Juni 2020

Sumber: (Miles, M. B., Huberman, M. A., \& Saldana, 2014)

Gambar 2. Teknik Analisis Data Miles and Huberman

\section{HASIL PENELITIAN DAN PEMBAHASAN}

Hasil data penelitian yang dikumpulkan dari wawancara, observasi, dan dokumentasi kepada seluruh subjek penelitian menggambarkan tingkat pemahaman guru berdasarkan level rendah, sedang, dan tinggi. Data yang dihimpun dari 40 subjek yaitu guru PAUD di Yogyakarta yang tersebar di 4 wilayah kabupaten.

Seluruh subjek penelitian menyampaikan hal yang positif terkait permainan tradisional Jamuran. Semua menyatakan setuju bahwa permainan tradisional Jamuran dapat dijadikan media pembelajaran dan mampu mengembangkan khususnya usia 5-6 tahun.

Subjek juga menyampaikan pendapat yang sama, dengan memanfaatkan permainan tradisional Jamuran dalam kegiatan di sekolah menjadi bagian dari pelestarian dan mengenalkan sejak dini budaya Indonesia. Sebagian besar responden menyatakan bahwa aspek yang paling besar dikembangkan melalui permainan ini adalah sosial emosional atau kerjasama.

Hasil penelitian juga menunjukkan bahwa, sebagian besar subjek penelitian belum mengetahui aspek lain selain sosial emosional yang dapat dikembangkan ketika anak memainkan permainan tradisional Jamuran. Mayoritas subjek juga berpendapat bahwa permainan tradisional Jamuran perlu perencanaan yang sangat matang dan tidak mudah apabila dijadikan sebagai kegiatan inti pembelajaran dan lebih memilih sebagai kegiatan insidental atau pada momen tertentu dengan tema kebudayaan.

Terkait tingkat pengetahuan subjek penelitian tentang permainan tradisional Jamuran dibagi menjadi tiga yaitu, rendah, sedang, dan tinggi. Secara garis besar diperoleh data yang tergambarkan dalam tabel 1. sebagai berikut;
Tabel 1. Tingkat Pengetahuan Guru tentang Permainan Jamuran

\begin{tabular}{ccr}
$\begin{array}{c}\text { Tingkat } \\
\text { Pengetahuan }\end{array}$ & \multicolumn{2}{c}{ Pemahaman Guru } \\
\hline & $-\begin{array}{l}\text { Menyebutkan langkah } \\
\text { permainan Jamuran sesuai }\end{array}$
\end{tabular}
pengalamannya

- Menyebutkan peralatan yang dibutuhkan dalam permainan sesuai dengan pengalamannya

- Menyebutkan manfaat dari permainan tradisional Jamuran sebagai bentuk pelestarian budaya

- Menceritakan asal mula permainan tradisional Jamuran pengalaman

- Mendeskripsikan 2 aspek yang dapat dikembangkan melalui permainan tradisional Jamuran, yaitu sosial emosional dan fisik motorik.

- Menyebutkan terlalu sulit memasukkan permainan Jamuran dalam kegiatan inti pembelajaran

- Menyebutkan langkah permainan Jamuran sesuai buku manual pembelajaran PAUD dan mengenali adanya penyesuaian kebermanfaatan bagi AUD

- Menyebutkan peralatan yang dibutuhkan dalam permainan sesuai buku manual dan mengenali tidak ada perubahan dari pengalaman terdahulu

Sedang - Menceritakan asal mula permainan tradisional Jamuran berdasarkan pengalaman dan buku manual

- Menyebutkan manfaat dari permainan tradisional Jamuran sebagai salah satu aktivitas pembelajaran terutama dalam kegiatan pengenalan budaya

- Menceritakan asal mula permainan tradisional 


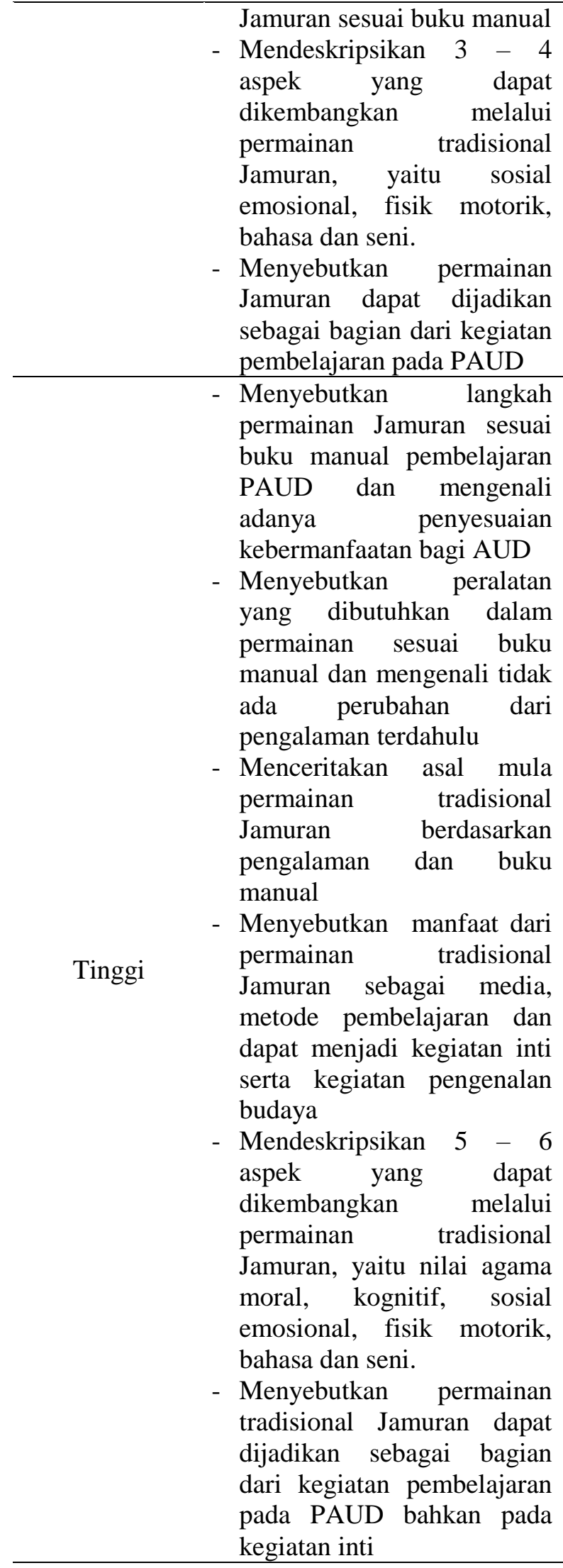

Sumber: Hasil wawancara, observasi, dan dokumentasi selama penelitian

Tabel 1. diatas tingkat pengetahuan guru dapat menyebutkan gambaran karakteristik permainan Jamuran meliputi langkah permainan, peralatan yang digunakan, manfaat, sejarah, tujuan umum dan khusus. Secara umum guru menguasai tingkat pengetahuan tentang permainan tradisional Jamuran. Sebagaimana pendapat (Gunawan, Iman \& Palupi, 2012), proses kognitif berdasarkan Taksonomi Bloom Revisi tingkat pengetahuan meliputi mengenali dan mengingat kembali. Untuk mengenali pengetahuan dibentuk dari mengindentifikasi suatu pengetahuan. Sedangkan mengingat kembali memiliki komponen yaitu mengambil pengetahuan dari memori yang dimiliki.

Pengetahuan guru sebagai subjek penelitian tentang permainan tradisional Jamuran apabila dilihat unsurnya dapat dikatakan telah menguasai taksonomi Bloom tingkat pengetahuan. Hal tersebut diperkuat oleh pendapat (Darmawan, I P. Ayub \& Sujoko, 2013), tingkat pengetahuan dalam taksonomi Bloom resvisi yaitu mengingat kembali dengan memanggil pengetahuan dari memori yang telah disimpan sebelumnya dengan unsur mengenali dan mengingat. Meskipun tingkat pengetahuan guru telah sesuai dengan unsur dalam taksonomi Bloom, namun apabila dilihat terdapat gradasi pengetahuan yang berbeda.

Tabel 1. Memperlihatkan gradasi tingkat pengetahuan guru dari rendah, sedang, dan tinggi. Setiap level dalam tingkatan pengetahuan menggambarkan ranah pengetahuan guru yang sebenar-benarnya. Dari level tersebut, dapat dijadikan sebagai gambaran akan pengetahuan guru dalam memahami permainan tradisional Jamuran dan dapat dijadikan sebagai dasar untuk melakukan asesmen awal tentang proses pembelajaran yang telah guru lakukan. 
Berikut penjelasan untuk setiap item pengetahuan yang didapat selama proses penelitian.

Pertama, Tabel 1. tingkat pengetahuan guru dalam menyebutkan langkah permainan, peralatan yang digunakan, dan asal mula permainan Jamuran di level rendah terlihat guru hanya mampu mengingat kembali sesuai dengan pengalamannya terdahulu. Hal tersebut menunjukkan bahwa hanya ada 1 dari 2 unsur pengetahuan yaitu mengingat kembali namun tidak mengenali adanya perubahan ingatan dimasa sekarang. Berdasarkan pendapat (Darmawan, I P. Ayub \& Sujoko, 2013), dalam unsur pengetahuan terdapat 2 unsur yaitu mengingat kembali dan mengenali. Dapat dikatakan subjek pada level rendah belum mengusai kemampuan kognitif dalam permainan tradisional Jamuran terutama untuk langkah permainan dan aturan permainan.

Level pengetahuan sedang dan tinggi menunjukkan kemampuan yang hampir sama untuk ketiga item langkah permainan, aturan permainan, dan asal mula permainan Jamuran. Keduanya mampu menyebutkan sesuai dengan pengetahuan yang diperolehnya dari buku manual permainan tradisional untuk pembelajaran PAUD dan mengenali adanya penyesuaian. Hal tersebut menunjukkan bahwa guru tidak hanya menunjukkan kemampuan mengingat di masa lampau tetapi juga mampu mengenali adanya adaptasi dengan kondisi sekarang. Berdasarkan data tersebut dapat dikatakan subjek penelitian level sedang dan tinggi untuk tingkat pengetahuan memenuhi unsur penguasaan pengetahuan. Sebagaimana pendapat (Darmawan, I P. Ayub \& Sujoko, 2013) adanya dua unsur mengingat kembali dan mengenali suatu pengetahuan dari masa lampau.

Kedua, secara umum guru mampu menguasai tingkat pengetahuan, namun pada level rendah tingkat pengetahuan guru dalam mendeskripsikan manfaat sebagian besar guru hanya mampu menyebutkan 2 aspek yaitu sosial emosional dan fisik motorik. Sedangkan pada level sedang mampu menyebutkan 3-4 aspek kebermanfaatan permainan Jamuran, dan pada level tinggi mampu menyebutkan ke enam aspek kebermanfaatan. Berdasarkan data diatas hanya guru pada level tinggi dapat dikatakan mampu menguasai pengetahuan akan kebermanfaatan permainan Jamuran untuk pengembangan ke enam aspek dalam diri anak. Sebagaimana pendapat (Pramudyani, A. V. R., Kurniawan, M. R., Rasyid, H., Sujarwo, S., Utami, N. I., \& Vesiano, 2018), permainan tradisional Jamuran mampu mengembangkan 6 aspek perkembangan dalam diri anak meliputi nilai agama moral, kognitif, bahasa, fisik motorik, sosial emosional, dan seni.

Tingkat pengetahuan guru di level rendah dan sedang masih menganggap bahwa permainan tradisional Jamuran belum dapat dijadikan sebagai media dalam menstimulus kemampuan nilai agama dan moral anak. Namun berdasarkan pendapat (Pramudyani, A. V. R., Kurniawan, M. R., Rasyid, H., Sujarwo, S., Utami, N. I., \& Vesiano, 2018), permainan Jamuran dapat dijadikan sebagai pengembangan aspek nilai agama dan moral yaitu memahami aturan; mengenal hadiah dan hukuman; menghargai diri sendiri, oranglain, dan lingkungan sekitar sebagai rasa syukur kepada Tuhan YME; mencerminkan perilaku jujur, serta berperilaku santun. Hal tersebut sesuai dengan pendapat (Dharmamulya, dkk, 2005), nilai pendidikan yang dapat dikembangkan melalui permainan tradisional Jamuran salah satunya adalah aspek afeksi yaitu memahami aturan permainan, anak akan belajar taat pada aturan terlebih lagi aturan tersebut sudah menjadi kesepakatan bersama antara anggota pemain.

Demikain juga guru pada level rendah dan sedang belum memiliki pengetahuan akan permainan tradisional Jamuran mampu mengembangkan aspek kognitif. Meskipun menurut pendapat (Pramudyani, A. V. R., 
Kurniawan, M. R., Rasyid, H., Sujarwo, S., Utami, N. I., \& Vesiano, 2018), ketika anak memainkan permaianan tradisional Jamuran pada saat langkah permainan anak diluar lingkaran diminta untuk menjadi jamur tertentu, saat itu anak sedang mengembangkan kemampuan berimajinasi dan memahami simbol. Hal tersebut juga didukung oleh pendapat dari (Mutiah, 2015), berpikir simbolik adalah unsur dari kemampuan berpikir kognitif. Kemampuan ini bertujuan agar anak mampu membayangkan suatu objek secara mental meskipun tidak melihat secara langsung.

Begitu pula dengan kemampuan bahasa, guru di level rendah dan sedang belum mengetahui bahwa permainan tradisional Jamuran memiliki kebermanfaatan dalam mengembangkan bahasa pada anak usia dini. Sebagaimana hasil penelitian (Hartiwi, 2016), dengan permainan tradisional Jamuran dapat meningkatkan kemampuan berbicara sebagai bagian dari perkembangan aspek bahasa.

Dalam aspek sosial emosional seluruah guru dari level rendah, sedang, dan tinggi hanya mampu menyebutkan adanya kemampuan kerjasama dalam permainan Jamuran. Apabila dianalisis lebih mendalam permainan tradisional Jamuran tidak hanya mengembangkan kemampuan kerjasama dalam diri anak usia dini. Berdasarkan hasil penelitian (Putri, F. R. \& Dimyati, 2019), permainan tradisional Jamuran terbukti mampu meningkatkan kemampuan bertanggung jawab anak kepada diriya sendiri dan lingkungannya. Hal tersebut juga diperkuat oleh (Herawati, 2015), permainan Jamuran sekurang-kurangnya mampu mengembangkan kemampuan kerjasama, kreativitas, dan tanggung jawab.

Demikian juga dengan aspek fisik, seluruh guru sebagai subjek penelitian dari level rendah, sedang, dan tinggi memiliki pendapat yang sama terkait permainan tradisional Jamuran mampu mengembangkan kemampuan motorik kasar anak usia dini. Sebagaimana hasil penelitian (Rakimahwati, Rahkimahwati \& Putri F., 2017), permainan Jamuran sangat efektif dalam mengembangkan kemampuan motorik kasar bagi anak usia dini.

Permainan tradisional Jamuran merupakan salah satu bentuk kebudayaan sehingga tidak dapat dipungkiri memiliki nilai seni. Hal tersebut disepakati seluruh guru atau subjek dalam penelitian ini dari level rendah, sedang, dan tinggi. Sebagaimana kita ketahui, Jamuran adalah jenis permainan yang tergolong kepada permainan dengan aktivitas bernyanyi dan berdialog. Aktivitas bernyanyi adalah salah satu bentuk apresiasi karya seni, anak juga memapu mengebangkan kemampuan merespon nada dan irama sewaktu bermain Jamuran. Sebagaimana pendapat (Pramudyani, A. V. R., Kurniawan, M. R., Rasyid, H., Sujarwo, S., Utami, N. I., \& Vesiano, 2018), Jamuran mampu mengembangkan aspek seni dalam diri anak usia dini berupa kemampuan dalam bernyanti ketika menyanyikan lagu pengiring jamuran dan kemampuan merespon nada dan irama.

Ketiga, pada tabel 1. Permainan tradisional Jamuran di level rendah menyebutkan kesulitan mengintegrasikan pemainan Jamuran dalam pembelajaran inti pada PAUD. Hal tersebut menunjukkan bahwa pengetahuan guru di level rendah belum memperoleh informasi atau kebaharuan keilmuan bahwa permainan tradisional dapat dijadikan sebagai kegiatan inti pembelajaran. Sedangkan pada level sedang dan tinggi, mereka telah mengetahui bahwa permainan tradisional dapat menjadi salah satu alternatif kegiatan pembelajaran dalam kegiatan inti di PAUD sebagai sarana untuk menstimulasi keseluruhan perkembangan anak. Sebagaimana hasil penelitian (Khasanah, Ismatul; Prasetyo, Agung; \& Rakhmawati, 2011), permainan tradisional jawa dapat menjadi media pembelajaran untuk 
P ISSN 2548-6284 E ISSN 2615-0360

Vol. 4 No. 2 Juni 2020

menstimulasi keseluruhan aspek perkembangan anak. Hal tersebut juga diperkuat oleh hasil penelitian (Munawaroh, 2017) permainan tradisional mampu menjadi model pembelajaran dan menjadi sarana stimulasi semua aspek perkembangan anak usia dini.

Ketidaktahuan subjek penelitian di level rendah karena mereka belum pernah mendapatkan pelatihan secara khusus tentang pemanfaatan permainan tradisional untuk kegiatan pembelajaran. Hal tersebut didukung oleh hasil penelitian (Maryatun, I. B., Pamungkas, J., \& Christianti, 2017), masih ada $95 \%$ guru yang belum mampu mengembangankan tema pembelajaran berbasis budaya lokal karena belum pernah mendapatkan pelatihan khusus.

Kurangnya pengetahuan guru karena belum pernah mendapatkan pelatihan berdampak pada pemanfaatan permainan tradisional yang semestinya dapat menjadi kegiatan inti pembelajaran namun hanya dijadikan sebagai kegiatan tambahan yang tidak memiliki arti atau manfaat bagi aspek perkembangan anak usia dini. Hal tersebut diperkuat hasil penelitian (Pramudyani, A. V. R., Kurniawan, M. R., Rasyid, H., 2017), dari keseluruhan subjek penelitian masih ada $65 \%$ guru masih menjadikan kegiatan permainan tradisional sebagai kegiatan tambahan diluar kegiatan inti. Permainan traidisional hanya dijadikan sebagai sarana bermain selagi menunggu jam masuk sekolah atau dijemput orangtua.

\section{SIMPULAN}

Pengetahuan tentang permainan tradisional Jamuran bagi anak usia dini terbagi menjadi tiga level rendah, sedang, dan tinggi. Untuk level rendah dapat disimpulkan guru masih memerlukan pengetahuan lebih banyak agar dapat memanfaatkan permainan tradisional Jamuran sebagai sarana stimulasi. Sedangkan pada level sedang dan tinggi pengetahuan yang dimiliki cukup sebagai dasar bagi guru untuk mengembangkannya.

\section{DAFTAR PUSTAKA}

Anderson, Lorin W. \& Krathwohl, D. R. (2010). Kerangka Landasan Untuk Pembelajaran, Pengajaran, dan Asesmen (1st ed.). Pustaka Pelajar.

Darmawan, I P. Ayub \& Sujoko, E. (2013). Revisi Taksonomi Pembelajaran Benyamin S. Bloom. Satya Widya: Jurnal Penelitian Dan Pengembangan Pendidikan, 29(1), 30-39. https://doi.org/https://doi.org/10.24246/j.sw. 2013.v29.i1.p30-39

Dharmamulya, dkk, S. (2005). Permainan Tradisional Jawa. Kepel Press.

Gunawan, Iman \& Palupi, R. A. (2012). Taksonomi Bloom- Revisi Ranah Kognitif: Kerangka Landasan Untuk Pembelajaran, Pengajaran, dan Penilaian. Premiere Educandum: Jurnal Pendidikan Dasar Dan Pembelajaran, 2(2), 98-117. https://doi.org/10.25273/pe.v2i02.50

Hartiwi, D. \& Z. D. A. (2016). Peningkatan Kemampuan Berbicara Melalui Permainan Tradisional Jamuran Pada Anak Kelompok Bermain Di Paud Taman Belia Candi Tahun Pelajaran 2015/2016. PAUDIA: Jurnal Penelitian Dalam Bidang Pendidikan Anak Usia Dini, 5(2), 51-66. https://doi.org/10.26877/paudia.v5i2.1182

Herawati, E. N. (2015). Nilai-Nilai Karakter Yang Terkandung Dalam Dolanan Anak Pada Festival Dolanan Anak Se-DiY 2013. Imaji: Jurnal Seni Dan Pendidikan Seni, 13(1). https://doi.org/https://doi.org/10.21831/imaji .v13i1.4045

Khasanah, Ismatul; Prasetyo, Agung; \& Rakhmawati, E. (2011). Permainan Tradisional Sebagai Media Stimulasi Aspek Perkembangan Anak Usia Dini. Jurnal Penelitian PAUDIA, 1(1), 105. https://doi.org/http://dx.doi.org/10.26877/pa udia.v1i1.261

Krathwohl, D. R. (2002). A Revision of Bloom's Taxonomy: An Overview. Theory Into Practice, 41(4), 212-218. https://doi.org/https://doi.org/10.1207/s1543 0421tip4104_2

Manning M, Garvis S, Fleming C, W. T. W. G. (2017). The relationship between teacher qualification and the quality of the early childhood care and learning environment (No.

1891-1803). https://doi.org/10.4073/csr.2017.1

Maryatun, I. B., Pamungkas, J., \& Christianti, M. (2017). Kemampuan Guru TK di Yogyakarta Dalam Mengembangkan Tema Pembelajaran Berbasis Budaya Lokal. Jurnal Penelitian Ilmu Pendidikan, 10(1). https://doi.org/doi:10.21831/jpipfip.v10i1.16 791 
P ISSN 2548-6284 E ISSN 2615-0360

Vol. 4 No. 2 Juni 2020

Miles, M. B., Huberman, M. A., \& Saldana, J. (2014). Qualitative Data Analysis: A Method Sourcebook (E. H. Salmon (ed.); Fourth Edi). SAGE Publication.

Munawaroh, H. (2017). Pengembangan Model Pembelajaran dengan Permainan Tradisional Engklek Sebagai Sarana Stimulasi Perkembangan Anak Usia Dini. Obsesi : Jurnal Pendidikan Anak Usia Dini, 1(2), 86 96.

https://doi.org/https://doi.org/10.31004/obses i.v1i2.19

Mutiah, D. (2015). Psikologi Bermain Anak Usia Dini (1st ed.). Prenadamedia Group.

Pancaningrum, N. (2016). Strategi Pembelajaran: Taksonomi Bloom Dalam Games Stimulation Method di Tingkat RA. ThufulA: Jurnal Inovasi Pendidikan Guru RA, 4(1), 112-129.

https://doi.org/http://dx.doi.org/10.21043/thu fula.v4i1.1939

Pramudyani, A. V. R., Kurniawan, M. R., Rasyid, H., Sujarwo, S., Utami, N. I., \& Vesiano, Q. A. (2018). Buku Panduan Permainan Tradisional Berdasarkan Aspek Perkembangan AUD (C. Alviana (ed.); 1st ed.). Samudra Biru.

Pramudyani, A. V. R., Kurniawan, M. R., Rasyid, H., \& S. (2017). Kurikulum Holistik Integratif Berbasis Permainan Tradisional Pada PAUD Di Yogyakarta. Jurnal Penelitian Ilmu Pendidikan, 10(2), 86-96. https://doi.org/doi: 10.21831/jpipfip.v10i2.17910

Putri, F. R. \& Dimyati, D. (2019). Jamuran Game in Improving 4- to 6-year-old Children's Responsibility at TK Nasional Samirono, Yogyakarta. In A. \& N. A. N. P. Wardana, Amika; Aman (Ed.), Proceedings of the 2nd International Conference on Social Science and Character Educations (ICoSSCE 2019) (pp. 245-248). Atlantis Press. https://doi.org/https://dx.doi.org/10.2991/ass ehr.k.200130.050

Rakimahwati, Rahkimahwati \& Putri F., R. (2017). Efektiveness Jamuran Game to Increase the Children's Gross Skill at Pendidikan Anak Usia Dini Terpadu Tunas Bangsa Bukittinggi. In A. \& D. H. Widanarto, Ghanis Putra; Hasjiandito (Ed.), Proceedings of the 9th International Conference for Science Educators and Teachers (ICSET
Tingkat Pengetahuan Guru .... Avanti Vera Risti Pramudyani

2017) (pp. 374-377). Atlantis Press. https://doi.org/https://dx.doi.org/10.2991/ics et-17.2017.62

Sanjaya, W. (2015). Penelitian Pendidikan: Jenis, Metode, Prosedur (Edisi Pert). Prenadamedia Group.

Whittington, Susie M.; Stup, E. R. B. L. \& A. E. (1997). Assesment of Cognitive Discourse: A Study of Thingking Opportunities Provided by Professors. Journal of Agricultural Education, 38(1), 46-53. https://doi.org/10.5032/jae.1997.01046

Wulandari, A. G. Id. \& Su. W. I. (2018). Guru Kreatif Anak Usia Dini Melalui Pendekatan Taksonomi Bloom. PRATAMA WIDYA: Jurnal PAUD, 3(2), 37-40. https://doi.org/http://dx.doi.org/10.25078/pw .v3i2.736 